Original Paper http://ajol.info/index.php/ijbcs http://indexmedicus.afro.who.int

\title{
Proliferation of the water hyacinth (Eichhornia crassipes) on the river Sô (Sô-Ava) in Bénin
}

\author{
M. Oscar Euloge FATON ${ }^{1 *}$, Léopold Simplice GNANCADJA ${ }^{1}$, \\ Lambert Cloud HINVI ${ }^{2}$, Agapit Dossou WOUYOU ${ }^{1}$, Dénis TONON ${ }^{1}$, \\ A. Patrick EDORH ${ }^{3}$, Luc KOUMOLOU ${ }^{3}$, Christophe GANDONOU ${ }^{1}$ \\ and Monique TOSSOU ${ }^{4}$
}

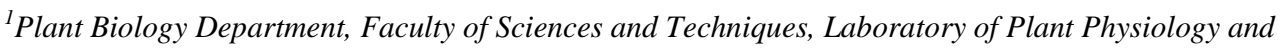 \\ Environmental Stress Study, University of Abomey-Calavi, Cotonou, Bénin. \\ ${ }^{2}$ Hydrobiology Laboratory and Aquaculture, University of Abomey-Calavi, Cotonou, Bénin. \\ ${ }^{3}$ Laboratory of Biochemistry and Cell Biology, University of Abomey-Calavi, Cotonou, Bénin. \\ ${ }^{4}$ Plant Biology Department, Botanical Laboratory and Plant Ecology, University of Abomey-Calavi, Cotonou, \\ Bénin. \\ *Corresponding author; E-mail: oscarfaton@yahoo.fr;081BP7142 Cotonou, Bénin.
}

\begin{abstract}
Water hyacinth is a plant from America which was imported in Africa as an ornamental plant but because of its proliferation, has become a dangerous aquatic macrophyte. In Benin, it colonizes most courses in continental water. Water hyacinth is present in several areas of the world as an ornamental plant and its infestation can be controlled by several treatments. The objective of this work is to identify them and promote their valuation in order to reduce their dangerousness to the population of aquatic organism as well as their ecosystem. In this regard, a survey was carried out to overcome these problems the people of the town in SôAva and around face every year on the Sô River flows into Lake Nokoue. The coverage of the water hyacinth (Eichhornia crassipes) is a major problem for people living in those areas where the plants rage. This plant prevents the movement of motorized boats, prevents the penetration of oxygen in water, which greatly reduces the number of organism such as fish fry, crocodiles nest and boas.
\end{abstract}

(c) 2015 International Formulae Group. All rights reserved.

Keywords: Eichhornia crassipes, Sô river, aquatic weed, biological control.

\section{INTRODUCTION}

Water hyacinth (Eichhornia crassipes), is a macrophyte floating aquatic plant that grows on the surface or in the mud of rivers. His presence in infested areas of tropical and subtropical countries caused serious economic and environmental consequences (Ghabbour et al., 2004; Center et al., 2005). The plant, due to the height and density it can reach, may reduce light and oxygen dissolved in water. This suffocation of aquatic life affects its ecosystem balance. It also hinders water transport, fishing activities and clogs taken hydroelectric dams and irrigation networks 
(Dembélé et al., 1994). Harly (1990) and Gutirrezet (1994) reported that under the reproductive capacity of the hyacinth, its adaptability, food requirements and its resistance to adverse conditions it is so far impossible to eradicate Eichhornia crassipes once introduced in a new area. Although the infestation of hyacinth (begun in the early $20^{\text {th }}$ century) worldwide is known, its current expansion is poorly understood. During the past decade, its rapid spread in tropical and subtropical Africa has caused environmental crises and irrigation. Sustainable management of Eichhornia crassipes infestation has turned toward biological control using natural enemies such as insects and plant pathogens (Ajuonu et al., 2003). In agriculture, biological control is a method used against a pest or weed throught antagonists of natural organisms such as herbivores, parasitoids, the predators or pathogens (viruses, bacteria, fungi) (FAO, 1997). After a development bringing significant results in agriculture, this technique of elimination or of control of opponents of human activities spread invasive exotic species colonizing natural habitats. Thus, more generally, biological control can be considered as the use of a living organism as a regulating agent considered nuisance species (Beisel and Lévesque, 2010). The ecological and economic damage caused by the spread of invasive exotic species are beginning to be better assessed like are investment management cost implemented to remedy them. Control methods conventionally used (mechanical management, use of pesticides, etc...) are costly, sometimes complexes to implement, not always effective and can have unwanted environmental impacts. In a context of optimization of management cost and improved performance, the issue of biological control often comes up in debates. The method seems attractive, economical, easy to implement, applicable on a large scale and without damage to the environment. Several interesting works have been done in the area. For example in his review of biological control of aquatic nuisance, Schuytema (1977) consulted more than 500 references and reviewed all organisms can be used. He also integrated opportunities called biomanipulation using changes in environmental conditions such as: reduction of the light, the content of water nutrients, etc., or interspecific interactions such as selection of fish species for the control of the phytoplankton, or the introduction of plants aerating a competition with weeds. Beetles (Neochetina eichhorniae species) have been widely used for a long time; Beisel and Lévesque (2010) indicate that among the hundreds species of insects tested on water hyacinth, a dozen has been shown to cause significant foliar damages. And those weevils are used in the USA, Africa and China. Schuytema (1997) also quotes the use of rust currently being studied in Argentina on the same plant. The objective of this work is to identify them and to promote their valuation in order to reduce their dangerousness to the population of aquatic organism as well as their ecosystem.

\section{MATERIALS AND METHODS \\ Materials}

The river Sô of Sô-Ava area is the chosen for our investigation. The plant material that was the subject of this survey at the Sô River is the water hyacinth.

\section{Study area}

The town Sô-Ava (Figure 1) is bounded to the south by the municipality of Cotonou, to the west by the municipality of Calavi. The main income generating activities are fishing, fish farming and market gardening in ponds, in floating cage as well as acadjas. 


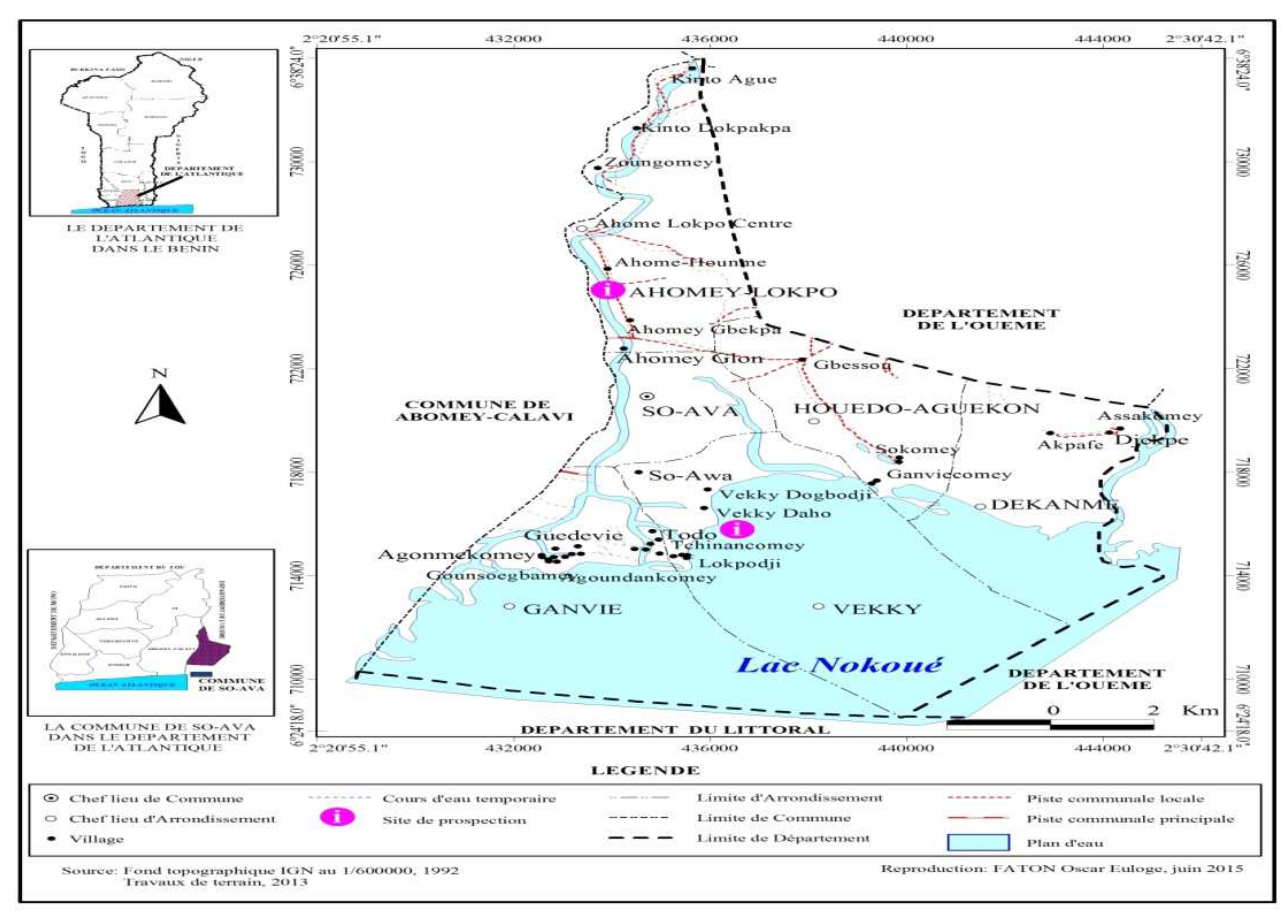

Figure 1: Map of the prospecting site (FATON, 2015).

\section{Methods}

Surveys were conducted in two target districts: Ahomey-Dokpo which is composed of eight villages along the Sô River and Vekky which includes all five villages on the water. Our mission was conducted over two seasons: April during the wet season and September during the dry season. These surveys were respectively made with students, peasants, officials all categories capita, NGOs and local authorities inhabitants of the area investigating the management of water hyacinth during rainy seasons when the plant hugely.

\section{Data analysis}

Data processing by test khi2 of Pearson focused on the analysis on the opinion of those surveyed people on the destruction of water hyacinth.

\section{RESULTS}

At the end of our investigations, we reached the following results:

The graph of Figure 2 shows the favourable and unfavourable opinion on the outcome of investigations carried out. Thus $87.27 \%$ in the district of Vekky and $87.06 \%$ in that of Ahomey-Dokpo favour the total destruction of the water hyacinth in the two districts. In the opposite, $12.73 \%$ respectively of the same districts remain resistant to its destruction because they use much of water hyacinth to feed their animals.

The graph 3, showing the favourable and unfavourable opinions of different groups of people surveyed in reducing water hyacinth density on the Sô River, depends significantly on the group of people surveyed with the proportions in the figure.

The analysis of the graph shows that peasants and students think that the presence of water hyacinth on the river makes difficult 
access to their homes and to a lesser extent kills fry. Officials and NGO staffs think that the water hyacinth is a mosquito nest. However, local authorities think that water hyacinth can feed pigs and its stem is an excellent material for making ornamental objects.

\section{Biomass of the water hyacinth in river Sô of Sô-Ava}

From Table 3, the dry weight of the water hyacinth varies from $1.3 \mathrm{~kg} / \mathrm{m}^{2}$ to 3.2 $\mathrm{kg} / \mathrm{m}^{2}$ in wet season while in dry season; it varies from $1.1 \mathrm{~kg} / \mathrm{m}^{2}$ to $1.2 \mathrm{~kg} / \mathrm{m}^{2}$. The fresh weight of water hyacinth in the dry season varies from $12.42 \mathrm{k} / \mathrm{m}^{2}$ to $17.5 \mathrm{~kg} / \mathrm{m}^{2}$ while in the wet season; it varies $28.14 \mathrm{~kg} / \mathrm{m}^{2}$ to 30.45 $\mathrm{kg} / \mathrm{m}^{2}$. The biomass in dry season varies from $10.3 \mathrm{~kg} / \mathrm{m}^{2}$ to $15.5 \mathrm{~kg} / \mathrm{m}^{2}$. In wet season, it varies from $27.5 \mathrm{~kg} / \mathrm{m}^{2}$ to $19.5 \mathrm{~kg} / \mathrm{m}^{2}$.

\section{Threats and consequences of water hyacinth on Sô River of Sô-Ava}

According to our surveys Eichhornea crassipes increasingly invades the river Sô of Sô- Ava and becomes a gene for fishing . It prevents waterfowls to hunt their prey; it is also a haven for crocodiles. Water hyacinth tarnishes the landscape of water and causes blockage of tourist canoes which reduces the income of the municipality of Sô-Ava. Water hyacinth also proliferates in the river downstream and which communicate with SôAva. Ecologically, it alters the functioning of aquatic ecosystems and causes losses of species. Dense mats of this invasive species prevent water penetration of solar radiation and this reduces photosynthesis of primary producers at the base of food chains (Kpondjo, 2008). Those dense mats impede navigation, preventing river transport and docking canoes or other mobility aids. The plant goes up to block the propellers of transert and fishing gear. Finally the environment created by water hyacinth encourage the development of some disease vectors such as Malaria Filariasis (Dagno et al., 2007).

Table 1: Floral list of hydrophyte and helophytes of Sô-Ava.

\begin{tabular}{|c|c|c|c|c|}
\hline $\mathbf{N}^{\circ}$ & Species & Family & Biological types & $\begin{array}{l}\text { Abundance } \\
\text { dominance }\end{array}$ \\
\hline 1 & Azolla pinnata & Azollaceae & Hydrophyte free floating & + \\
\hline 2 & Eichhornia crassipes & Pontederiaceae & $\begin{array}{l}\text { Hydrophyte } \\
\text { free floating }\end{array}$ & +++ \\
\hline 3 & Ipomoea indica & Convolvulaceae & Lyane Helophyte & + \\
\hline 4 & Lemna perpusilla & Lemnaceae & Hydrophyte submerged floating & + \\
\hline 5 & Panicum maximum & Poaceae & Helophyte & + \\
\hline 6 & Shastata alvinia & Salviniaceae & Helophyte & + \\
\hline 7 & Cyperus prolifer & Cyperaceae & Helophyte & + \\
\hline 8 & Neptunia oleracea & Nympheaceae & Helophytefree floating & + \\
\hline 9 & Cyperus asculentus & Cyperaceae & Helophyte & + \\
\hline 10 & Colocasia aquorum & Araceae & Helophyte & + \\
\hline 11 & Typha angustifolia & Typhaceae & Helophyte & + \\
\hline
\end{tabular}


Table 2: Water hyacinth in the river Sô of Sô-Ava: density, size number of stolons and biology.

\begin{tabular}{|c|c|c|}
\hline Site $\mathbf{N}^{\circ}$ & Site I & Site II \\
\hline \multicolumn{3}{|c|}{ Density according the season } \\
\hline humidity & 58 & 48 \\
\hline Dryer & 18 & 19 \\
\hline \multicolumn{3}{|c|}{ Average longth of the raines according to the season } \\
\hline humidity & 0,38 & 0,47 \\
\hline Dryer & 0,32 & 0,40 \\
\hline \multicolumn{3}{|c|}{ Number of individual with stolons according to the seasons } \\
\hline Humidity & 2 & 2 \\
\hline Dryer & 1 & 2 \\
\hline \multicolumn{3}{|l|}{ Fresh weight } \\
\hline Humidity & 28,14 & 18,14 \\
\hline In the dry season & 12,42 & 17,5 \\
\hline \multicolumn{3}{|c|}{ Dry weight $\left(\mathrm{kg} / \mathrm{m}^{2}\right)$ according to the season } \\
\hline Humidity & 1,3 & 3,2 \\
\hline Dryer & 1,1 & 1,2 \\
\hline \multicolumn{3}{|c|}{ Biomass according to the season } \\
\hline Humidity & 27,5 & 19,5 \\
\hline Dryer & 10,3 & 15,5 \\
\hline \multicolumn{3}{|l|}{ Biology hyacinth } \\
\hline \multirow[t]{3}{*}{ Moisture season } & Flowers & In the vegetative state \\
\hline & Slender petiols & Petiole \\
\hline & Long roots and high leaves & Aerifere flower in trace \\
\hline Dry season & In the vegetative state & In the vegetative state \\
\hline
\end{tabular}

Table 3: Khi2 Pearson tests for independence of the opinion for or against the investigation.

\begin{tabular}{lcc}
\hline & $\mathbf{X}^{\mathbf{2}}$ & Probability \\
\hline Sex & 0,9693 & 0,3249 \\
Level of education & 7,0518 & 0,2168 \\
Districts & 0 & 1 \\
Catégories & 9,5461 & 0,049 \\
\hline
\end{tabular}




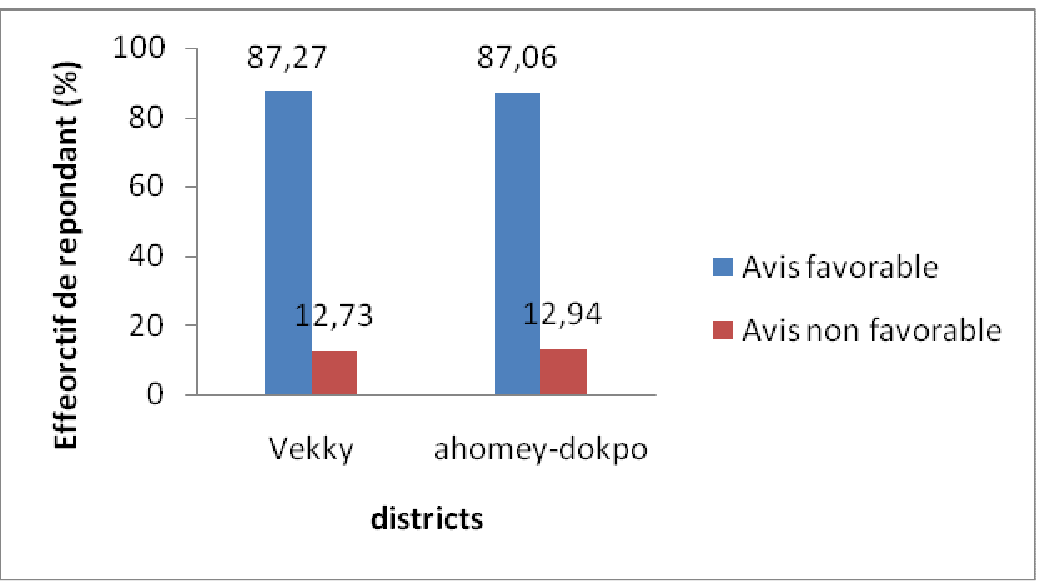

Figure 2: Diagram showing the favorable and unfavorable opinion of surveyed people at the district level.

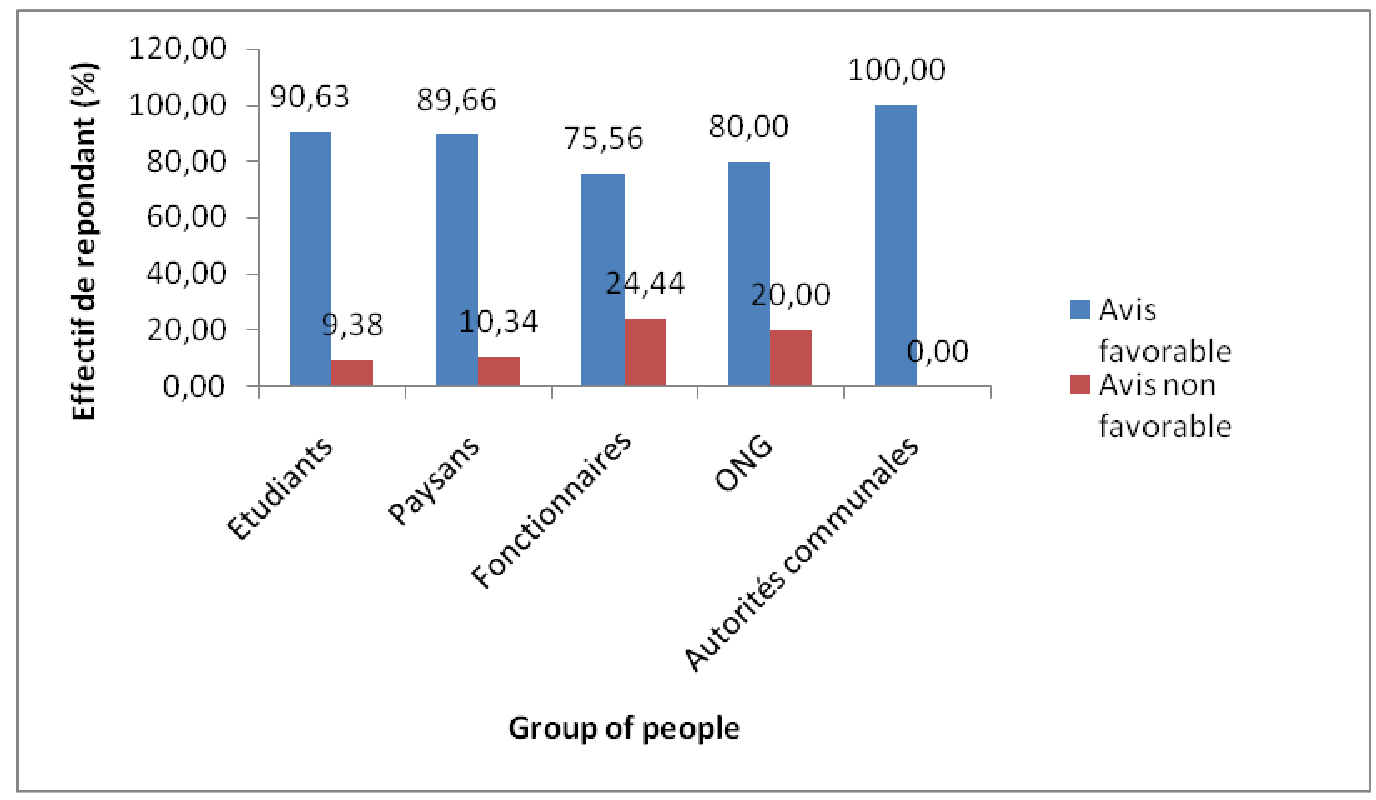

Figure 3: Diagram showing the views of the different groups of people surveyed on reducing water hyacinth density on the Sô River. 


\section{CA factor map}

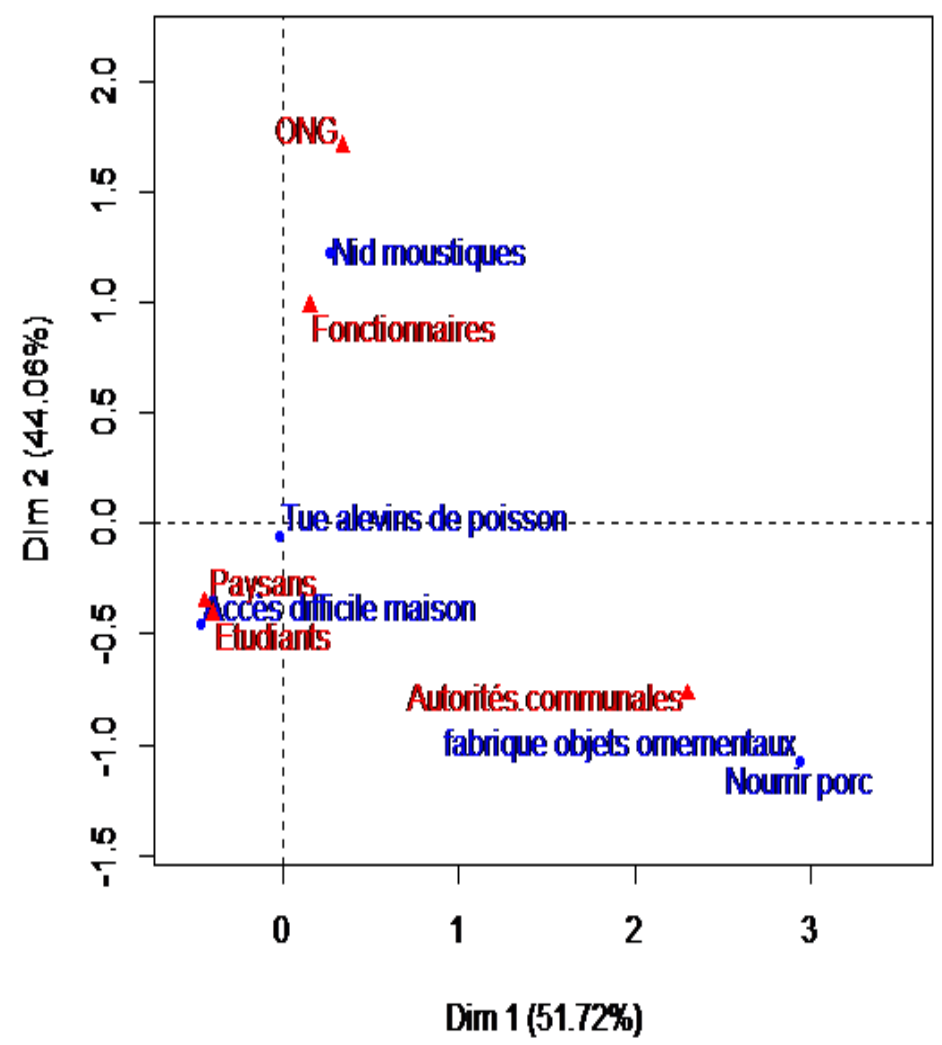

Figure 4: Projection of perceptions and different group of people surveyed on axis.

\section{DISCUSSION}

Several countries are exposed to the problem of infestation of water hyacinth but the case of Benin has not been published mean while the water hyacinth proliferate in different wetlands especially the river Sô in the town of Sô-Ava and surroundings. This results in asphyxiation of animals such as fish and turtles. The plant, because of the height and density, reduces the light and oxygen under water ( Dango et al., 2006). In addition, it is a threat to overfishing and illegal logging. This plant causes damage to fishing equipments because of its tangle of line in the root system. In the area of our investigation, the ardent wish of the people is to look for effective ways to fight against the proliferation of the water hyacinth apart from the mechanical or manual fight against the plant that provides rather short term control of its proliferation (Picterse et al., 1996) . According to Gutierrez (1996), the mechanical method requires heavy equipments to collect water. Regarding chemical control, several herbicides as effective against water hyacinth are applied by air or ground treatment . $2.4 \mathrm{~d}(2.4$ dichlorophenoxyacetic acid) usually applied by air spraying at rate of 1 to $2 \mathrm{~km} / \mathrm{ha}$ provides effective control, especially when applied during warm periods (Gopal, 1987). The disadvantages of chemical control lie not only on the destruction of the aquatic ecosystem as well as the adverse effects of residues of herbicides, but also on the environment and the health of the population, for this population collects drinking water in the rivers (Harly et al., 1997). The long term application 
of the same herbicide can cause the application of resistance in the water hyacinth (Babu et al., 2003). Biological control could be an interesting alternative to chemical control. This fight against hyacinth has been developed in the 1960s by importing insects from the Amazon basin of brazil. This struggle is based on the use of natural enemies of the plant in order to create constant pressure on it. These means of struggling against the proliferation of the water hyacinth in the river Sô of Sô-Ava were used without great solution against the plant. A thorough study is needed to identify the responsible agents of this rapid proliferation of the plant in the area where our survey was conducted. The analysis of the diagram 2 shows that peasants and students have revealed that the presence of water hyacinth on the so river makes it difficult to access their homes and to a lesser extent kills fish fry (Fiogbe. 2011). Officials and NGOs staffs think that the water hyacinth is a mosquito net. However, local authorities think that one can use water hyacinth (Eichlornia crassipes) to feed pigs and its stem is an excellent material for making ornamental objects. The consent of the surveyed people in reducing the water hyacinth density in so river is not significantly dependent on the sex, the level of education of districts and on the group of surveyed. They think that one must look for effective ways to fight against the species that is becoming increasingly dangerous.

\section{Conclusion}

Water hyacinth has become a scourge in the town of Sô-Ava which is on the river Sô. His presence causes great problems both ecological and economic hydro agricultural and especially those who live on the river. It threatens the conservation of aquatic animals especially the one of endemic species threatened. The dry wet of water hyacinth varies from $1.3 \mathrm{~kg} / \mathrm{m}^{2}$ to 3.2 $\mathrm{kg} / \mathrm{m}^{2}$ to $1.2 \mathrm{~kg} / \mathrm{m}^{2}$. The fresh wet of water hyacinth in the dry season varies from $12.42 \mathrm{~kg} / \mathrm{m}^{2}$ to $17.5 \mathrm{~kg} / \mathrm{m}^{2}$ while in the wet season it varies from $28.14 \mathrm{~kg} / \mathrm{m}^{2}$ to $30.45 \mathrm{~kg} / \mathrm{m}^{2}$. The biomass in dry season varies from $10.3 \mathrm{~kg} / \mathrm{m}^{2}$ or $100.3 \mathrm{t} /$ ha to 15.5 $\mathrm{t} / \mathrm{ha}$. In wet season, it varies from 27.5 $\mathrm{kg} / \mathrm{m}^{2}$ or 270.5 to $19.5 \mathrm{~kg} / \mathrm{m}^{2}$ or $190.5 \mathrm{t} / \mathrm{ha}$. This biomass power upsets aquatic life. The extent of damage caused by proliferation in the municipality of Sô-Ava and on the ecosystem is proved. The mechanic fight could be applied but it is very expensive because of the use of machinery. This chemical would not be recommended for conservation. The biological control of insects and mycoherbicides gave encouraging results in other countries. It could be recommended but requires an ecological monitoring of introduced insects and an environmental impact study. It is then necessary at the end of our investigation to seek effective ways that can reduce the water hyacinth density on the so river that will be used in other areas were the plant also raged.

\section{COMPETING INTERESTS}

The authors declare that they have no competing interests.

\section{REFERENCES}

Ajuonu O, Schade V, Veltman B, Sedjro K, Neuenschwander P. 2003. Impact of the weevils Neochetina eichhorniae and N. bruchi (Coleoptera: Curculionidae) on water hyacinth, Eichhornia crassipes (Pontederiaceae), in Benin, West Africa. Afr. Entomol., 11(2): 153-171.

Babu RM, Sajeena A, Seetharaman K 2003. Bioassay of the potentiality of Alternaria alternata (Fr.) Keissler as a bio herbicide to control water hyacinth and other aquatic weeds. Crop. Prot., 22: 10051013.

Beisel JN, Lévesque C. 2010. Introduction d'espèces dans les milieux aquatiques, $45 \mathrm{p}$. 
Center TD, Pratt PD, Rayamajhi MB, Van TK, Francs SJ, Dray FA, Rebelo MT. 2005. Herbivory alters competitive between two invasive aquatic plants. Biol. Control., 33(2): 173-185.

Dagno K. 2006. Evaluation des microorganismes fongiques en tant qu'agents de lutte biologique contre Eichhornia crassipes (Martius) SolmsLaubach dans le bassin du fleuve Niger au Mali. DEA Doc. Sci. agron. Gembloux, Belgique : Gembloux Agricultural University - FUSAGx, $102 \mathrm{p}$.

Dagno K, Lahlali R, Friel D, Bajji M, Jijakli M H. 2007. Synthèse bibliographique: problématique de la jacinthe d'eau, Eichhornia crassipes, dans les régions tropicales et subtropicales du monde, notamment son éradication par la lutte biologique au moyen phytopatogènes. Biotechnol.Agron. Soc. Environ., 11(4): 299-311.

Deloach CJ, Cordo HA, Crouzel IS. 1989. Control Biologic de Malezas. El Atenoe : Buenos Aires, Argentina ; 26.

Dembélé B. 1994. La jacinthe d'eau, un fléau pour les cours d'eau au Mali. CILSS, Sahel PVinfo., 63: 8.

FAO. 1997. Lutte intégrée contre la jacinthe d'eau et autres plantes aquatiques nuisibles. Rome: FAO: Document de Projet $\mathrm{n}^{\circ}$ TCP/MLI 66/13 A.

Fiogbe ED. 2011 Effets des luttes menées contre les plantes aquatiques proliférantes sur l'écologie des plans d'eau du Bénin. Rapport d'étape $\mathrm{N}^{\circ} 2$ du projet de gestion intégrée des plantes aquatiques proliférantes, Cotonou Bénin, 49p.

Fiogbe ED. 2011. Effets des lutes menées contre les plantes aquatiques proliférantes sur l'écologie des plans d'eau du Bénin. Rapport d'étape $\mathrm{N}^{\circ} 3$ du projet de gestion intégrée des plantes aquatiques proliférantes, Cotonou Bénin, 108p.

Gutiérrez LE, Huerto DR, Martinez JM. 1996. Water hyacinth problems in Mexico and practiced methods for control, 125-135.

Gopal B. 1987. Water Hyacinth. Elsevier: Amsterdam, the Netherlands; 471.

Harley KLS, Julien M H, Wright AD. 1997. Water hyacinth: A tropical worldwide problem and methods for its control. Proceedings of the first meeting of the International Water Hyacinth Consortium, 18-19 March. Washington, World Bank.

Kpondjo NM. 2008. Développement des larves de moustiques dans un écosystème particulier milieu sous jacinthe d'eau (Eichhornia crassipes), 32p.

Pieterse AH, Mangane A, Traoré M, Van DG, Van RPJ. 1996. The water hyacinth problem in West Africa and proposals for control strategies in strategies for water hyacinth control, 11-14.

Schuytema K. 1977. Interactions between fishers and aquatic macrophytes in inlands Water. 52p. 